\title{
Genome-wide association study revealed genomic regions related to white/red earlobe color trait in the Rhode Island Red chickens
}

Changsheng $\mathrm{Nie}^{1 \dagger}$, Zebin Zhang ${ }^{1 \dagger}$, Jiangxia Zheng ${ }^{1 \dagger}$, Hongyan Sun ${ }^{2}$, Zhonghua Ning $^{1}$, Guiyun Xu', Ning Yang ${ }^{1}$ and Lujiang $\mathrm{Qu}^{1 *}$

\begin{abstract}
Background: Earlobe color is a naturally and artificially selected trait in chicken. As a head furnishing trait, it has been selected as a breed characteristic. Research has demonstrated that white/red earlobe color was related to at least three loci and sex-linked. However, there has been little work to date to identify the specific genomic regions and genes response to earlobe color in Rhode Island Red chickens. Currently, it is possible to identify the genomic regions responsible for white/red earlobe in Rhode Island Red chicken to eliminate this gap in knowledge by using genome-wide association (GWA) analysis.

Results: In the present study, genome-wide association (GWA) analysis was conducted to explore the candidate genomic regions response to chicken earlobe color phenotype. Hens with red dominant and white dominant earlobe was used for case-control analysis by Illumina $600 \mathrm{~K} \mathrm{SNP}$ arrays. The GWA results showed that $2.38 \mathrm{Mb}$ genomic region (50.13 to $52.51 \mathrm{Mb}$ ) with 282 SNPs on chromosome Z were significantly correlated to earlobe color, including sixteen known genes and seven anonymous genes. The sixteen genes were PAM, SLCO4C1, ST8SIA4, FAM174A, CHD1, RGMB, RIOK2, LIX1, LNPEP, SHB, RNF38, TRIM14, NANS, CLTA, GNE, and CPLX1.

Conclusions: The study has revealed the white/red earlobe trait is polygenic and sex-linked in Rhode Island Red chickens. In the genome significant $\sim 2.38 \mathrm{Mb}$ region, twenty-three genes were found and some of them could play critical roles in the formation of white/red earlobe color, especially gene SLCO4C1. Taken together, the candidate genes findings herein can help elucidate the genomic architecture of response to white/red earlobe and provide a new insight on mechanisms underlying earlobe color in Rhode Island Red chickens and other breeds.
\end{abstract}

Keywords: Rhode Island Red chicken, Earlobe color, GWAS

\section{Background}

Earlobe color, a qualitative trait in chicken, is artificially and naturally selected in various breeds $[1,2]$. It is a part of skin structure on the face without feathers and below the ear. In nature, shining color is selected to get more attention of their predators or partners [3, 4]. Earlobe color, a head furnishing trait, has been selected as a breed characteristic. Red or white earlobes are

\footnotetext{
* Correspondence: quluj@163.com

${ }^{\dagger}$ Equal contributors

${ }^{1}$ Department of Animal Genetics and Breeding, College of Animal Science and Technology, China Agricultural University, Beijing 100193, China Full list of author information is available at the end of the article
}

predominant in a number of the wild and domestic chickens worldwide [2] although yellow, blue, purple and black earlobe could be found in some breeds.

Variation in chicken earlobe color may be caused by ancestral lineages and mutations [2], as well as the adaptability to local conditions [5]. For example, The presence of white earlobes is due to purine base deposition and the formation of other color earlobe is attributed to the mixture of different pigments including melanin or carotenoid [6]. The red earlobe, the same color as the rest of the red face, could reflect the health of the birds with the degree of redness [7]. 
Genetic foundation studies of chicken earlobe color were conducted in previous studies. The white earlobe has been identified to be polygenic and it appeared to be sex-linked in some breeds [7]. The mottled earlobe in Rhode Island Reds appears to be produced by two recessive autosomal genes [8]. Recently, Wragg et al. [9] identified 7 concordant significances $(P<0.05$ and $Z>4)$ SNPs on chicken chromosomes 1, 2, 4 and $Z$ related to white/red earlobe color by using genome-wide association (GWA) analysis, indicating that earlobe color trait is sex-linked and polygenic. However, there has been little work to date to identify the accurate genomic regions and genes response to earlobe color in Rhode Island Red chickens. To eliminate this gap in knowledge, we performed a genome-wide association study (GWAS) to identify the genomic regions responsible for white/red earlobe in the Rhode Island Red chickens.

\section{Results}

After quality control, a total of 78 female chickens aged 20 weeks old were analyzed, of which 48 (61 \%) presented white earlobe color as cases and 30 (39\%) presented red earlobe color as controls. The MultiDimensional scaling (MDS) analysis indicated the absence of population stratification in our study population (Additional file 1: Figure S1).

Based on the Manhattan plot for earlobe color, we observed a total of 282 significantly associated SNPs spanning from 50.13 to $52.51 \mathrm{Mb}(\sim 2.38 \mathrm{Mb})$ on chromosome $\mathrm{Z}$ ( $\mathrm{P}$ value $<9.81 \times 10^{-7}$ ) in the sexually mature hens (Fig. 1 and Additional file 2: Table S1). The linkage disequilibrium plot (Additional file 3: Figure S2) showed the detected SNP markers were strongly linked in a haplotype block. Moreover, in this 2.38 spanning, twenty-three genes were found related to earlobe color phenotype, including sixteen annotated genes and seven anonymous genes: PAM, SLCO4C1, ST8SIA4, FAM174A, CHD1, RGMB, RIOK2, LIX1, LNPEP, SHB, RNF38,
TRIM14, NANS, CLTA, GNE, CPLX1, LOC107052343, LOC107052344, LOC107052345, LOC101752070, LOC107052346, LOC100857660 and LOC101752249. The sixteen annotated genes and their functions were displayed in Table 1.

Additionally, a total of four autosomal regions with 6 SNPs were suggestive significantly related to white/red earlobe in chicken $\left(1.95 \times 10^{-5}\right)$ (Fig. 1 and Additional file 4: Table S2), of which two on chromosome 2 (one with 2 SNPs and the other one with 1 isolated SNP) (67.19 $\mathrm{Mb} \sim 67.21 \mathrm{Mb}$ ), one on chromosome 5 (1 isolated SNP), and one on chromosome 7 (2 SNPs) (10.09 Mb 10.12 Mb).

\section{Discussion}

The aims of this study were to identify and estimate the genomic regions responsible for white/red earlobe in Rhode Island Red chickens, and to locate positional candidate genes association with color earlobe by using a 600 K SNP panel for genotyping. In a brief, a total of 282 genome significantly SNP markers on chromosome $\mathrm{Z}$ were detected in this study, which corresponded to sixteen known genes and seven anonymous genes.

Gene SLCO4C1 (solute carrier organic anion transporter family member 4C1) was identified for earlobe color within an average of $101 \mathrm{~kb}$ of twenty-five the genome-wide significant SNPs (Additional file 2: Table $\mathrm{S} 1$ ). This plausible positional candidate gene, SLCO4C1, may have its special function in earlobe color formation as it is among numerous significant SNPs that in linkage disequilibrium (LD) building up to a QTL peak.

Candidate gene, SLCO4C1, belongs to the organic anion transporting polypeptide (OATP) family. Researchers have demonstrated that OATP family had the function of transportation of the amphipathic organic compounds, like bile salt in mammals [10, 11]. The component of bile salt, biliverdin, can be deposited to

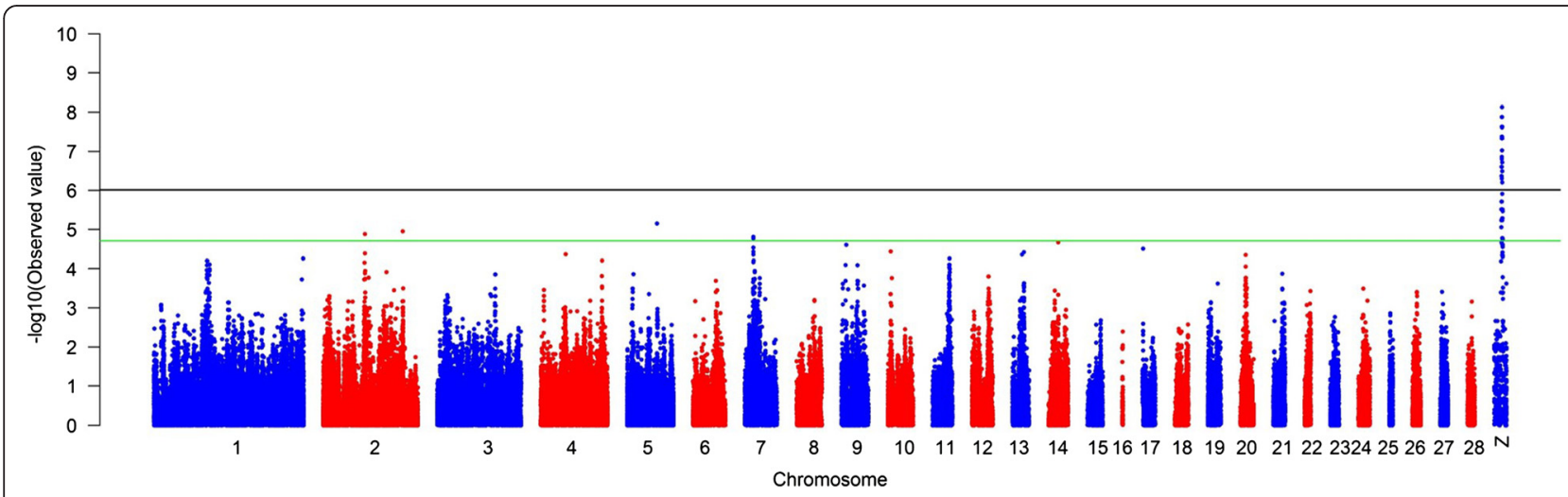

Fig. 1 Manhattan plot of genome wide association study for white/red earlobe color. The Manhattan plot indicates -log10 (observed P-values) for genome-wide SNPS ( $y$-axis) plotted against their respective positions on each chromosome ( $x$-axis), and the horizontal green and black lines indicate the suggestive significant $(1.95 \times 10-5)$ and genome-wide significant $(9.81 \times 10-7)$ threshold, respectively 
Table 1 Summary description of genes in $\sim 2.38 \mathrm{Mb}$ region on chromosome $Z$

\begin{tabular}{|c|c|c|c|c|c|}
\hline Gene & Full Name & $\begin{array}{l}\text { Location } \\
(\mathrm{bp})^{\mathrm{a}}\end{array}$ & $\begin{array}{l}\text { Length } \\
(\mathrm{bp})^{\mathrm{a}}\end{array}$ & $\begin{array}{l}\text { Number } \\
(\text { SNP) }\end{array}$ & Functions \\
\hline PAM & $\begin{array}{l}\text { Peptidylglycine alpha-amidating } \\
\text { monooxygenase }\end{array}$ & $\begin{array}{l}50,043,929- \\
50,172,820\end{array}$ & 128,892 & 7 & $\begin{array}{l}\text { Catalyze neuroendocrine peptides to active alpha- } \\
\text { amidated products }[17,30] \text {, type } 2 \text { diabetes [13]. }\end{array}$ \\
\hline SLCO4C1 & $\begin{array}{l}\text { Solute carrier organic anion } \\
\text { transporter family member } 4 \mathrm{C} 1\end{array}$ & $\begin{array}{l}50,256,470- \\
50,283,287\end{array}$ & 26,818 & 2 & Transport estrone 3-sulfate [31]. \\
\hline ST8SIA4 & $\begin{array}{l}\text { ST8 alpha-N-acetyl-neuraminide } \\
\text { alpha-2,8-sialyltransferase } 4\end{array}$ & $\begin{array}{l}50,646,216- \\
50,699,691\end{array}$ & 53,476 & 0 & $\begin{array}{l}\text { Modulator of the adhesive properties of neural cell } \\
\text { adhesion molecule [16]. }\end{array}$ \\
\hline LOC107052343 & NA & $\begin{array}{l}50,802,139 \\
50,808,822\end{array}$ & 6,684 & 0 & NA \\
\hline FAM174A & $\begin{array}{l}\text { Family with sequence similarity } 174 \\
\text { member A }\end{array}$ & $\begin{array}{l}50,808,437- \\
50,822,236\end{array}$ & 13,800 & 0 & NA \\
\hline CHD1 & $\begin{array}{l}\text { Chromodomain helicase DNA } \\
\text { binding protein } 1\end{array}$ & $\begin{array}{l}51,274,317- \\
51,322,737\end{array}$ & 48,421 & 0 & Disease related $[12,32,33,34]$. \\
\hline$R G M B$ & $\begin{array}{l}\text { Repulsive guidance molecule family } \\
\text { member b }\end{array}$ & $\begin{array}{l}51,334,306- \\
51,349,990\end{array}$ & 15,685 & 0 & Angiogenesis [35], breast cancer [14]. \\
\hline RIOK2 & RIO kinase 2 & $\begin{array}{l}51,538,065- \\
51,550,090\end{array}$ & 12,026 & 0 & Mitotic progression [36], cytoplasmic maturation [18]. \\
\hline$L I X 1$ & Limb and CNS expressed 1 & $\begin{array}{l}51,552,825- \\
51,581,108\end{array}$ & 28,284 & 0 & Fat signaling, marker for cerebral structures $[19,37]$. \\
\hline LNPEP & Leucyl/cystinyl aminopeptidase & $\begin{array}{l}51,598,066- \\
51,651,403\end{array}$ & 53,338 & 13 & $\begin{array}{l}\text { Vasopressin clearance and serum sodium regulation [38], } \\
\text { associated with psoriasis [39]. }\end{array}$ \\
\hline LOC107052344 & NA & $\begin{array}{l}51,667,644- \\
51,675,321\end{array}$ & 7,678 & 1 & NA \\
\hline$S H B$ & $\begin{array}{l}\text { Src homology } 2 \text { domain containing } \\
\text { adaptor protein } \mathrm{B}\end{array}$ & $\begin{array}{l}51,704,167- \\
51,777,551\end{array}$ & 73,385 & 14 & Regulates cell motility $[40,41]$. \\
\hline LOC107052345 & NA & $\begin{array}{l}51,759,503- \\
51,766,981\end{array}$ & 7,479 & 4 & NA \\
\hline RNF38 & Ring finger protein 38 & $\begin{array}{l}51,958,739- \\
51,993,024\end{array}$ & 34,286 & 9 & Disease related $[15,42]$. \\
\hline LOC101752070 & NA & $\begin{array}{l}51,999,295- \\
52,003,026\end{array}$ & 3,732 & 0 & NA \\
\hline TRIM14 & Tripartite motif containing 14 & $\begin{array}{l}52,003,922- \\
52,011,357\end{array}$ & 7,436 & 3 & $\begin{array}{l}\text { A mediator in the immune response against viral infection } \\
\text { [43]. }\end{array}$ \\
\hline NANS & $\mathrm{N}$-acetylneuraminic acid synthase & $\begin{array}{l}52,013,130- \\
52,022,024\end{array}$ & 8,895 & 3 & Change expression in response to androgen [44]. \\
\hline CLTA & Clathrin light chain A & $\begin{array}{l}52,040,355- \\
52,055,158\end{array}$ & 14,804 & 2 & $\begin{array}{l}\text { Main structural component of the lattice-type cytoplasmic } \\
\text { face of coated pits and vesicles }[22,23] \text {. }\end{array}$ \\
\hline GNE & $\begin{array}{l}\text { Glucosamine (UDP-N-acetyl)-2- } \\
\text { epimerase }\end{array}$ & $\begin{array}{l}52,058,958- \\
52,096,177\end{array}$ & 37,220 & 10 & GNE myopathy [45], regulator of sialic acid synthesis [46]. \\
\hline LOC107052346 & NA & $\begin{array}{l}52,149,755- \\
52,175,567\end{array}$ & 25,813 & 9 & NA \\
\hline LOC100857660 & NA & $\begin{array}{l}52,178,755- \\
52,205,231\end{array}$ & 26,477 & 6 & NA \\
\hline CPLX1 & Complexin 1 & $\begin{array}{l}52,264,659- \\
52,368,798\end{array}$ & 104,140 & 18 & $\begin{array}{l}\text { Synaptic vesicle exocytosis, bind syntaxin, part of the SNAP } \\
\text { receptor }[21,47,48] \text {. }\end{array}$ \\
\hline LOC101752249 & NA & $\begin{array}{l}52,471,803- \\
52,483,455\end{array}$ & 11,653 & 2 & NA \\
\hline
\end{tabular}

NA not available

a Source: Reference Gallus_gallus-5.0 primary assembly (NCBI)

${ }^{b}$ The number of genome significant SNPs located in gene

form blue eggshell [12]. Wang et al. [12] reported in chicken SLCO1B3 was in response to blue eggshell color formation via transferring biliverdin. Although the molecule transfer mechanism of earlobe color formation remains unknown, earlobes color was occurred due to purine base deposition or mixture of different pigments [6]. In practical, breeders believed some relations exist between earlobe and eggshell color, which might be 
caused by the close association of the determining genes on the chromosome or single factor that controls the pigmentation of both egg and earlobe [7].

Thus, based on the current results, pigments deposition to form earlobe color, as well as the relations between earlobe and eggshell color, it is reasonable for us to speculate SLCO4C1 may play an important role in the formation of earlobe color. Future validation of this assumption of SLCO4C1 gene function is warranted in chicken.

Besides the crucial positional candidate gene SLCO4C1, other candidate genes located in this $\sim 2.38 \mathrm{Mb}$ region have various functions (Table 1). For example, RNF38, CHD1, PAM, RGMB, LNPEP, RNF38, TRIM14 and GNE were detected to be associated with diseases [12-15]. ST8SIA4, PAM, RIOK2, LNPEP, LIX1, $S H B, T R I M 14$ and GNE have been discovered to be important in regulating the life process [16-20]. NANS can change expression in response to androgen. CPLX1 and RIOK2 were correlated with cytoplasmic maturation [18] or synaptic vesicle exocytosis [21]. CLTA was found associated with cytoplasmic face of coated pits [22] and vesicles progress [23]. Currently, the mechanism underlying earlobe color is almost unknown and few literatures support these candidate genes were directly in response to earlobe color. However, the GWAS results in this study may provide a clue for researcher to identify the relationship between these candidate genes and earlobe color. Further validation experiment of these genes was needed to perform.

Compared to our findings, Wragg et al. [9] has found 7 SNPs significantly associated with white/red earlobe color in various breeds via GWAS. In the study of Wragg et al., two SNPs (rs14170217 and rs14170463) were located on chromosome 2 at region $41.69 \mathrm{Mb}$ and $41.89 \mathrm{Mb}$, respectively [9], which were $\sim 25.5 \mathrm{Mb}$ and $\sim 25.3 \mathrm{Mb}$, respectively, downstream of our suggestive significantly SNPs (rs315420052 and rs313803643). The SNPs, rs14170217 and rs14170463, in Wragg et al. study were in the intron of genes, ATP2C1 and MRPL3, respectively. In our study, both rs315420052 and rs313803643 were in the intron of gene GMDS. Another SNP, rs14762712, on chromosome $\mathrm{Z}$ at $32.08 \mathrm{Mb}$ in Wragg et al. study [9] was also in intron in BNC2 that important to pigment pattern formation. In summary, all detected significant SNPs in Wragg et al. study were in the intron area of genes. Only $B N C 2$ was more related to earlobe color, which is not found in our study.

Several reasons made the different results between ours and Wragg et al. study. Firstly, Wragg et al. use traditional breeds, Kenyan, Ethiopian, and Chilean village chickens to perform association analysis. Secondly, the phenotypic traits in Wragg et al. study were not only earlobe but yellow skin, oocyan, rose comb, and duplex comb. Thirdly, the experimental population birds almost have been post-prune in earlobe color in Wragg's study. Moreover, compared to Wragg's materials, our inbreeding population has a different phenotype in earlobe (Additional file 5: Figure S3) but a consistent genetic background, which is a good choice to perform GWAS. Also, GWAS always show different results in different populations [24]. Taken together, it is not surprise to obtain different results from ours and Wragg et al. study. However, both Wragg et al. and our study showed polygenic and sex-linked inheritance pattern determined earlobe color although different breeds were used in different studies.

\section{Conclusions}

This study has revealed 282 genome significantly SNPs spanning $\sim 2.38 \mathrm{Mb}$ region on chromosome $\mathrm{Z}$ associated with earlobe color in Rhode Island Red chickens, corresponding to twenty-three genes. The genomic regions that we identified contain twenty-three genes with functions that suggest a role in response to earlobe color and, thus, these genes are both positional and functional candidates. Notably, among these twenty-three genes, SLCO4C1 may play critical roles in the formation of white/red earlobe color. Taken together, the candidate genes findings herein can help elucidate the genomic architecture of response to white/red earlobe and provide a new insight on mechanisms underlying earlobe color in Rhode Island Red chickens and other breeds.

\section{Methods}

\section{Animals and phenotypic data}

A total of 78 adult females Rhode Island Red chicken (20 weeks) were selected herein including 30 with red or predominantly red earlobe and 48 with white or predominantly white earlobe to perform GWAS (Fig. 2). In Rhode Island Red chicken, earlobe color trait is sexlinked. Males mainly had red earlobe whereas female had four grades of earlobe color: red, predominately red, white, and predominately white (Additional file 5: Figure S3). Animals have different phenotypes with a consistent genetic background is a good choice to do GWAS. Therefore, we chose sexually mature female chickens as experimental material to identify the genomic architecture of response to earlobe color in this study. In this experimental population, predominately red (Additional file 5: Figure S3b) or predominately white (Additional file 5: Figure S3c) is shown that red or white color overspread the majority of the earlobe surface. Blood samples were collected by standard venipuncture from a Rhode Island Red chicken population maintained at a commercial breeding farm in Beijing, China. 


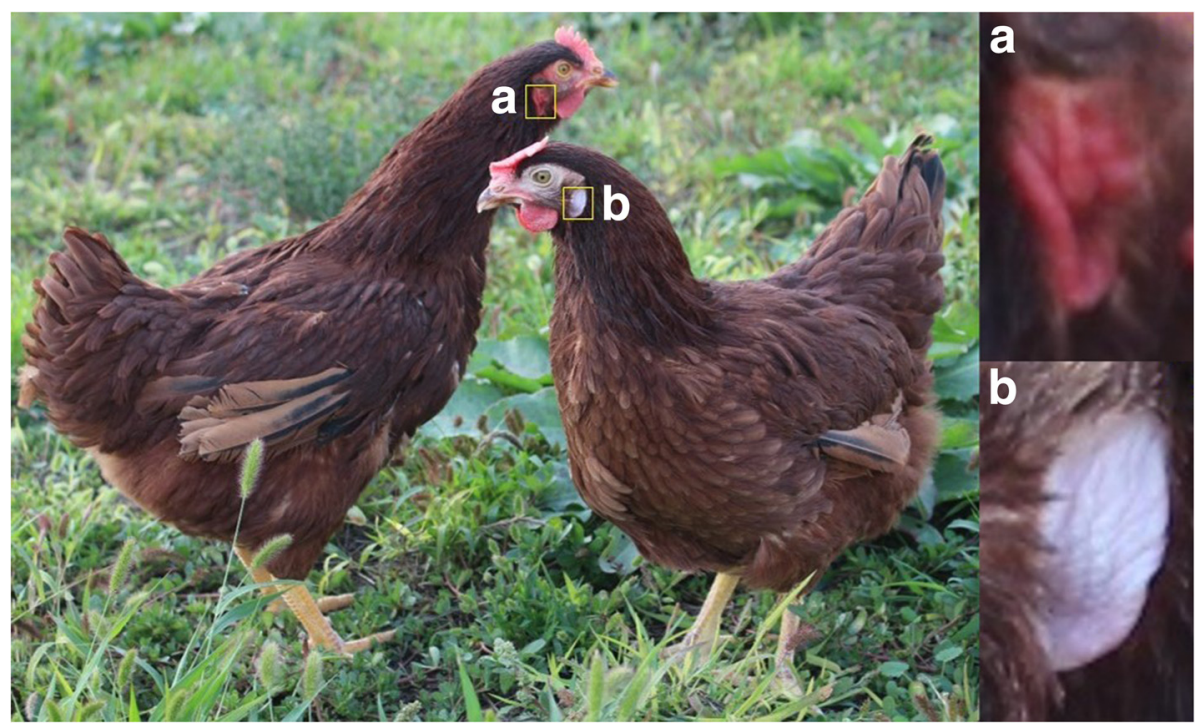

Fig. 2 Rhode Island Red chicken hens with the white or red earlobe color. a Red earlobe chicken, (b) white earlobe chicken.

\section{Genotyping and quality control}

Genomic DNA was extracted by standard phenol/ chloroform method and genotyped with $600 \mathrm{~K}$ Affymetrix Axiom Chicken Genotyping Array (Affymetrix, Inc. Santa Clara, CA, USA). Affymetrix Power Tools v1.16.0 (APT) software was then used for quality control and genotype calling. Specifically, only samples with dish quality control $(\mathrm{DQC})>0.82$ and call rate $>97 \%$ were used for subsequent analysis. After sample quality control analysis, the mean concordance rate was $99.7 \%$.

The classical multidimensional scaling (MDS) analysis was used to detect population structure in PLINK v1.09 software [25]. By computing identical by state (IBS) scores for unlinked SNPs with $\mathrm{r}^{2}<0.2$ and using multidimensional scaling, a total of 78 samples were identified to involve in further analysis. Projection onto the two multidimensional scaling axes is shown in Additional file 1: Figure S1.

SNPs were removed with a minor allele frequency < $5 \%$ in all samples $(n=135,166)$, or a $P$ value of deviation from HardyWeinberg equilibrium $\left(\mathrm{P}_{\mathrm{HWE}}\right)<1 \times 10^{-6}$ in controls $(n=444)$. Ultimately, a total of 78 individuals and 370,106 SNPs were kept for the following association analysis.

\section{Statistical analysis}

To test the association of each SNP with earlobe color, we used the basic case/control association analysis according to the manual of PLINK (v1.09). All qualified SNPs were subjected to the linkage disequilibrium via the --indep-pairwise $25 \quad 50.2$ commend (PLINK) to generate a pruned subset of 50,946 linkage equilibrium SNPs.
The Bonferroni adjustment is a widely used method for correcting multiple hypothesis testing. Given the correlation between SNPs in linkage disequilibrium, the traditional Bonferroni adjustment appears to be overly conservative which key assumption is that all tests are independent [26]. Herein, the sum of independent blocks plus singleton markers was used to define the number of independent statistical tests [27, 28]. With this approach, 50,946 independent tests were suggested to determine the $\mathrm{P}$ value threshold. Hence, the genomewide significant and suggestive $\mathrm{P}$ values were $9.81 \times 10^{-7}$ $(0.05 / 50946)$ and $1.95 \times 10^{-5}(1 / 50946)$, respectively. The Manhattan plot of genome wide $\mathrm{P}$ values of association analysis was created by self-developed $\mathrm{R}$ programming codes. To further location candidate region that affect trait, we performed linkage disequilibrium (LD) analysis with genome significantly SNPs in Haploview software (v4.2) [29].

\section{Additional files}

Additional file 1: Figure S1. Sample structure evaluated by the top two MDS components. (1) White earlobe chicken, (2) red earlobe chicken. (JPG $319 \mathrm{~kb}$ )

Additional file 2: Table S1. The information for SNPs significantly associated with earlobe color in Rhode Island Red chickens. (DOCX 37 kb)

Additional file 3: Figure S2. Linkage disequilibrium ( $r 2$ ) plot association with white/red earlobe color. (PNG $2459 \mathrm{~kb}$ )

Additional file 4: Table S2. Suggestive SNPS associated with the earlobe color phenotype in Rhode Island Red chickens. (DOC 240 kb)

Additional file 5: Figure S3. Rhode Island Red chicken hens with different earlobe color. (a) Red earlobe chicken, (b) predominately red earlobe chicken, (c) predominately white earlobe chicken, (d) white earlobe chicken. (JPG 131 kb) 


\section{Abbreviations}

DQC, dish quality control; GWAS, genome-wide association study; HD, high density; IBS, Identical by state; MDS, MultiDimensional scaling analysis

\section{Acknowledgments}

We are grateful for the help of all members of the poultry team of the National Engineering Laboratory for Animal Breeding.

\section{Funding}

This work was funded in part by the earmarked fund for the Beijing Innovation Team of the Modern Agro-industry Technology Research System (CARSPSTP) and National Scientific Supporting Projects of China (2015BAD03B03).

\section{Availability of data and materials}

The original data sets supporting the results of this article are available. They are not public, but are able to be accessed by request for result verification only.

\section{Authors' contributions}

$\mathrm{CN}$ and $\mathrm{ZZ}$ performed the experiments and analyzed the data. JZ, LQ, ZN, GX, and NY conceived and designed the experiment. CN and LQ wrote the manuscript. HS revised the manuscript. All authors read and approved the final manuscript.

\section{Competing interests}

The authors declare that they have no competing interests.

\section{Consent for publication}

Not applicable.

\section{Ethics approval and consent to participate}

All procedures and protocols involving animals were conducted in accordance with the Guidelines for the Care and Use of Experimental Animals established by the Ministry of Agriculture of China (Beijing, China). All animal work was approved by the Animal Welfare Committee of China Agricultural University (Beijing, China) (Permit Number: XK622).

\section{Author details}

${ }^{1}$ Department of Animal Genetics and Breeding, College of Animal Science and Technology, China Agricultural University, Beijing 100193, China. ${ }^{2}$ College of Animal Science and Technology, Yangzhou University, Yangzhou, Jiangsu 225009, China.

\section{Received: 22 February 2016 Accepted: 28 July 2016}

\section{Published online: 05 August 2016}

\section{References}

1. Salces AJ, Yebron Jr MGN, Salces CB, Dominguez JMD. Phenotypic and genetic characteristics of Boholano genetic group of Philippine native chicken (Gallus gallus domesticus, L.). Phil J Vet Animal Sci. 2015;41(1):1-11.

2. Cabarles Jr JC, Lambio AL, Vega SA, Capitan SS, Mendioro MS. Distinct morphological features of traditional chickens (Gallus gallus domesticus L.) in Western Visayas, Philippines. Animal Genet Resour. 2012;51:73-87.

3. Houde AE. Sex, color, and mate choice in guppies. Princeton: Princeton University Press; 1997.

4. Endler JA, Houde AE. Geographic variation in female preferences for male traits in Poecilia reticulata. Evolution. 1995;49:456-68.

5. Duguma R. Phenotypic characterization of some indigenous chicken ecotypes of Ethiopia. Livestock Res Rural Dev. 2006;18(9):article 131.

6. Smyth Jr JR. Genetics of plumage, skin and eye pigmentation in chickens. In: Developments in Animal and Veterinary Sciences (Netherlands) no 22. 1990.

7. Warren DC. Inheritance of earlobe color in poultry. Genetics. 1928;13(6):470-87.

8. Hays FA. Inheritance of mottled earlobes and stubs in Rhode Island Reds. Am Naturalist. 1943;77:471-5.

9. Wragg D, Mwacharo JM, Alcalde JA, Hocking PM, Hanotte O. Analysis of genome-wide structure, diversity and fine mapping of Mendelian traits in traditional and village chickens. Heredity. 2012;109(1):6-18.

10. Mikkaichi T, Suzuki T, Onogawa T, Tanemoto M, Mizutamari H, Okada M, Chaki T, Masuda S, Tokui T, Eto N, et al. Isolation and characterization of a digoxin transporter and its rat homologue expressed in the kidney. Proc Natl Acad Sci U S A. 2004;101(10):3569-74.

11. Ueno A, Masugi $Y$, Yamazaki $K$, Komuta M, Effendi $K$, Tanami $Y$, Tsujikawa $H$, Tanimoto A, Okuda S, Itano O, et al. OATP1B3 expression is strongly associated with Wnt/beta-catenin signalling and represents the transporter of gadoxetic acid in hepatocellular carcinoma. J Hepatol. 2014;61(5):1080-7.

12. Rodrigues LU, Rider L, Nieto C, Romero L, Karimpour-Fard A, Loda M, Lucia MS, Wu M, Shi L, Cimic A, et al. Coordinate loss of MAP3K7 and CHD1 promotes aggressive prostate cancer. Cancer Res. 2015;75(6):1021-34.

13. Steinthorsdottir V, Thorleifsson G, Sulem P, Helgason H, Grarup N, Sigurdsson A, Helgadottir HT, Johannsdottir H, Magnusson OT, Gudjonsson SA, et al. Identification of low-frequency and rare sequence variants associated with elevated or reduced risk of type 2 diabetes. Nat Genet. 2014;46(3):294-8.

14. Li J, Ye L, Sanders AJ, Jiang WG. Repulsive guidance molecule B (RGMB) plays negative roles in breast cancer by coordinating BMP signaling. J Cell Biochem. 2012;113(7):2523-31.

15. Girard L, Zochbauer-Muller S, Virmani AK, Gazdar AF, Minna JD. Genomewide allelotyping of lung cancer identifies new regions of allelic loss, differences between small cell lung cancer and non-small cell lung cancer, and loci clustering. Cancer Res. 2000;60(17):4894-906.

16. Schreiber SC, Giehl K, Kastilan C, Hasel C, Muhlenhoff M, Adler G, Wedlich D, Menke A. Polysialylated NCAM represses E-cadherin-mediated cell-cell adhesion in pancreatic tumor cells. Gastroenterology. 2008;134(5):1555-66.

17. Handa S, Spradling TJ, Dempsey DR, Merkler DJ. Production of the catalytic core of human peptidylglycine alpha-hydroxylating monooxygenase (hPHMcc) in Escherichia coli. Protein Expr Purif. 2012;84(1):9-13.

18. Zemp I, Wild T, O'Donohue MF, Wandrey F, Widmann B, Gleizes PE, Kutay U. Distinct cytoplasmic maturation steps of 405 ribosomal subunit precursors require hRio2. J Cell Biol. 2009;185(7):1167-80.

19. Moeller C, Yaylaoglu MB, Alvarez-Bolado G, Thaller C, Eichele G. Murine Lix1, a novel marker for substantia nigra, cortical layer 5, and hindbrain structures. Brain Res Gene Expr Patterns. 2002;1(3-4):199-203.

20. Cho A, Hayashi YK, Monma K, Oya Y, Noguchi S, Nonaka I, Nishino I. Mutation profile of the GNE gene in Japanese patients with distal myopathy with rimmed vacuoles (GNE myopathy). J Neurol Neurosurg Psychiatry. 2014;85(8):914-7.

21. Giraudo CG, Eng WS, Melia TJ, Rothman JE. A clamping mechanism involved in SNARE-dependent exocytosis. Science (New York). 2006; 313(5787):676-80.

22. Medendorp K, Vreede L, van Groningen JJ, Hetterschijt L, Brugmans L, Jansen PA, van den Hurk WH, de Bruijn DR, van Kessel AG. The mitotic arrest deficient protein MAD2B interacts with the clathrin light chain $A$ during mitosis. PLoS One. 2010;5(11):e15128.

23. Hennenberg M, Miersch J, Rutz B, Strittmatter F, Waidelich R, Stief CG, Gratzke C. Noradrenaline induces binding of Clathrin light chain A to alpha1-adrenoceptors in the human prostate. Prostate. 2013; 73(7):715-23.

24. Myles S, Davison D, Barrett J, Stoneking M, Timpson N. Worldwide population differentiation at disease-associated SNPs. BMC Med Genomics. 2008;1:22.

25. Purcell S, Neale B, Todd-Brown K, Thomas L, Ferreira MAR, Bender D, Maller J, Sklar P, de Bakker PIW, Daly MJ, et al. PLINK: A tool set for whole-genome association and population-based linkage analyses. Am J Hum Genet. 2007; 81(3):559-75.

26. Johnson RC, Nelson GW, Troyer JL, Lautenberger JA, Kessing BD, Winkler CA, O'Brien SJ. Accounting for multiple comparisons in a genome-wide association study (GWAS). BMC Genomics. 2010;11:724.

27. Nicodemus KK, Liu W, Chase GA, Tsai YY, Fallin MD. Comparison of type I error for multiple test corrections in large single-nucleotide polymorphism studies using principal components versus haplotype blocking algorithms. BMC Genet. 2005:6 Suppl:S78.

28. Gu X, Feng C, Ma L, Song C, Wang Y, Da Y, Li H, Chen K, Ye S, Ge C, Gu X, Feng C, Ma L, Song C, Wang Y, Da Y, Li H, Chen K, Ye S, Ge C, et al. Genome-wide association study of body weight in chicken $\mathrm{F} 2$ resource population. PLoS One. 2011;6(7):e21872.

29. Barrett JC, Fry B, Maller J, Daly MJ. Haploview: analysis and visualization of LD and haplotype maps. Bioinformatics (Oxford). 2005;21(2):263-5.

30. Simpson PD, Eipper BA, Katz MJ, Gandara L, Wappner P, Fischer R, Hodson EJ, Ratcliffe PJ, Masson N. Striking Oxygen Sensitivity of the Peptidylglycine alpha-Amidating Monooxygenase (PAM) in Neuroendocrine Cells. J Biol Chem. 2015;290(41):24891-901. 
31. Yamaguchi H, Sugie M, Okada M, Mikkaichi T, Toyohara T, Abe T, Goto J, Hishinuma T, Shimada M, Mano N. Transport of estrone 3-sulfate mediated by organic anion transporter OATP4C1: estrone 3-sulfate binds to the different recognition site for digoxin in OATP4C1. Drug Metab Pharmacokinetics. 2010;25(3):314-17.

32. Blake KD, Prasad C. CHARGE syndrome. Orphanet J Rare Dis. 2006; 1.

33. Burkhardt L, Fuchs S, Krohn A, Masser S, Mader M, Kluth M, Bachmann F, Huland H, Steuber T, Graefen M, et al. CHD1 is a 5 q21 tumor suppressor required for ERG rearrangement in prostate cancer. Cancer Res. 2013;73(9): 2795-805.

34. Rodgers MJ, Banks DJ, Bradley KA, Young JA. CHD1 and CHD2 are positive regulators of HIV-1 gene expression. Virol J. 2014;11:180.

35. Sanders AJ, Ye L, Li J, Mason MD, Jiang WG. Tumour angiogenesis and repulsive guidance molecule b: a role in HGF- and BMP-7-mediated angiogenesis. Int J Oncol. 2014:45(3):1304-12.

36. Liu T, Deng M, Li J, Tong X, Wei Q, Ye X. Phosphorylation of right open reading frame 2 (Rio2) protein kinase by polo-like kinase 1 regulates mitotic progression. J Biol Chem. 2011;286(42):36352-60.

37. Mao Y, Kucuk B, Irvine KD. Drosophila lowfat, a novel modulator of Fat signaling. Development (Cambridge, England). 2009;136(19):3223-33.

38. Nakada TA, Russell JA, Wellman H, Boyd JH, Nakada E, Thain KR, Thair SA, Hirasawa H, Oda S, Walley KR. Leucyl/cystinyl aminopeptidase gene variants in septic shock. Chest. 2011;139(5):1042-9.

39. Cheng H, Li Y, Zuo XB, Tang HY, Tang XF, Gao JP, Sheng YJ, Yin XY, Zhou FS, Zhang $C$, et al. Identification of a missense variant in LNPEP that confers psoriasis risk. J Investigative Dermatology. 2014;134(2):359-65.

40. Diakonova M, Gunter DR, Herrington J, Carter-Su C. SH2-Bbeta is a Racbinding protein that regulates cell motility. J Biol Chem. 2002;277(12): 10669-77.

41. Saldeen J, Kriz V, Agren N, Welsh M. SHB and angiogenic factors promote ES cell differentiation to insulin-producing cells. Biochem Biophys Res Commun. 2006;344(2):517-24.

42. Kim SK, Ro JY, Kemp BL, Lee JS, Kwon TJ, Fong KM, Sekido Y, Minna JD, Dong WK, Mao L. Identification of three distinct tumor suppressor loci on the short arm of chromosome 9 in small cell lung cancer. Cancer Res. 1997; 57(3):400-3.

43. Zhou Z, Jia X, Xue Q, Dou Z, Ma Y, Zhao Z, Jiang Z, He B, Jin Q, Wang J. TRIM14 is a mitochondrial adaptor that facilitates retinoic acid-inducible gene--like receptor-mediated innate immune response. Proceedings of the National Academy of Sciences of the United States of America. 2014;111(2): E245-254.

44. Romanuik TL, Wang G, Holt RA, Jones SJM, Marra MA, Sadar MD. Identification of novel androgenresponsive genes by sequencing of LongSAGE libraries. BMC Genomics. 2009; 10.

45. Nishino I, Carrillo-Carrasco N, Argov Z. GNE myopathy: current update and future therapy. Journal of neurology, neurosurgery, and psychiatry. 2015 86(4):385-92.

46. Hinderlich S, Weidemann W, Yardeni T, Horstkorte R, Huizing M. UDPGlcNAc 2-Epimerase/ManNAc Kinase (GNE): A Master Regulator of Sialic Acid Synthesis. Topics in current chemistry. 2015:366:97-137.

47. Krishnakumar SS, Radoff DT, Kummel D, Giraudo CG, Li F, Khandan L, Baguley SW, Coleman J, Reinisch KM, Pincet F, et al. A conformational switch in complexin is required for synaptotagmin to trigger synaptic fusion. Nature structural \& molecular biology. 2011;18(8):934-40.

48. Kummel D, Krishnakumar SS, Radoff DT, Li F, Giraudo CG, Pincet F, Rothman JE, Reinisch KM. Complexin cross-links prefusion SNAREs into a zigzag array. Nature structural \& molecular biology. 2011;18(8):927-33.

\section{Submit your next manuscript to BioMed Central and we will help you at every step:}

- We accept pre-submission inquiries

- Our selector tool helps you to find the most relevant journal

- We provide round the clock customer support

- Convenient online submission

- Thorough peer review

- Inclusion in PubMed and all major indexing services

- Maximum visibility for your research

Submit your manuscript at www.biomedcentral.com/submit
Biomed Central 